\title{
Implementation of District's Integrated Administration Service Policy (PATEN) in Gunung Putri District Bogor Regency
}

\author{
$1^{\text {st }}$ Munir Saputra ${ }^{1}, 2^{\text {nd }}$ A.H Rahadian ${ }^{2}$ \\ \{munir.saputra@stiami.ac.id ${ }^{1}$, rahadian.ah@gmail.com ${ }^{2}$ \} \\ Institut Ilmu Sosial dan Manajemen Stiami ${ }^{2}$
}

\begin{abstract}
The aim of research were analyzing the compliance degree of implementer toward the One-Stop Integrated Service policy, identifying the obstacles and problems found in the implementation of policy, and understanding the performance of output, outcome, benefit and impact of implementation of policy through the qualitative research approach by using the main theory proposed by Randall B. Repley and Grace A. Franklin (1986: 232-33). According to the research result, found that the compliance degree of implementer toward the regulation of laws was low because various Regent regulations concerning the implementation and determination of standard operational procedure not completely obeyed. Some problems were found such as in the aspect of Human Resources/Personnel, Budgeting, work facilities, computers and printer, regulations that consider to be changed frequently, and dependent organization of PATEN that caused the public principles services as stated in Laws No. 25 of 2009 not fully applied. The Performance of Services and the impact expected could not be measured because there was no document of work unit plan and complete LAKIP that accordance with the guidelines of report arrangement. From those three perspectives can be concluded that the implementation of PATEN policy in Gunung Putri District of Bogor Regency not work properly.
\end{abstract}

Keywords: Implementation of Policy, District's Integrated Administration Service (PATEN).

\section{Introduction}

One of the government entities that provide direct or indirect service to the public is district and village. As the sub-system of government in Indonesia, district has strategic position and have functional role in the practice of service and administration of government, development and community (Wasistiono, Nurdin, and Fahrurozi, $2009: 200$ ). In other words, District is the spearhead and barometer of implementation of public service and also as the storefront of implementation of regional government.

Gunung Putri is a district in Bogor Regency of West Java Province, Indonesia. It is directly bordered with Bekasi City in the North, Citeureup in the South, Depok in the West, and Cileungsi in the East. The population number is 453.696 people (report of BPS Bogor Regency, May 2017) which put it as the district with highest population in Bogor Regency. The number of district in Bogor Regency is 40 districts with total population on May 2017 of 5.715.009 people. 
The delegation of service in District level is started from the Laws No.32 of 2004 concerning the Regional Government which state that Camat (the Head of District) in carrying its duties, gained an abundance of authority from the Regent to handle some regional autonomy, thus District may become the spearhead as well as the barometer of service performance, including in Bogor Regency. According to the Laws then the Regulation of the Minister of Home Affairs Number 4 of 2010 concerning the Guidelines of District's Integrated Administration Service (PATEN) and the Decision of Minister of Home Affairs Number 138270 of 2010 Concerning the Technical Guideline of Integrated Administration Services (PATEN) are defined.

In the case improving the service quality, government has issued the laws No. 23 of 2014 concerning the Regional Government, but in Bogor Regency until the end of 2018 still use the Regulation of Minister of Home Affairs Number 4 of 2010 and the Decision of Minister of Home Affairs Number 138-270 of 2010, concerning the Integrated Administration Service (PATEN) as the reference.

The previous research about the implementation of PATEN in Bogor Regency and Gunung Putri District was conducted by Kosasih (2014) describing the service quality as less proper particularly concerning the poor implementer's competence and inadequate source of funds, lack of Human Resources as the implementer and the tendency of people in utilizing the third party to communicate with the implementer of PATEN. In addition, the people complaint delivered in social media (adminnusa 10/07/2018) shows the existence of high cost should be paid in processing the investment permit due to the brokering.

According to the observation result on the implementation of One-Stop Integrated Service, the service of PATEN in Gunung Putri District was limited on the civil service (not licensing) while the licensing service was handled by other department in the District of Gunung Putri.

Ripley and Franklin (in Winarno, 2014: 148) said that implementation is what occurred after the laws defined in which provide the authority of program, policy, benefit, or as a type of tangible output. Implementation includes the actions by the actors, particularly the intended bureaucrats to design a running program. Grindle (in Winarno, 2014: 149) proposed his opinion about implementation by stating that in general, the duty of implementation is creating a linkage that facilitate the purposes of policy in order to be realized as the impact of an activity of government.

In the Policy of Implementation and Bureaucracy, Randall B. Repley and Grace A. Franklin (1986: 232-33) (in Alfatih, 2010:51-52), wrote about three conceptions relating to successful implementation and said:

"The nation of success in implementation has no single widely accepted definition. Different analysts and different actors have very different meanings in mind when they talk about or think about successful implementation. There are three dominant ways of thinking about successful implementation"

In the relation with three dominant ways of thinking about successful implementation then they said that there was an analyst and actor who argue that the success implementation of policy is measured first, using the compliance degree. However, second, there is who measure the smoothness of routines of function. Since Ripley and Franklin consider the two parameters "is too narrow and have limits political interest", then they propose the third perspective that is the impact expected. They stated it by saying "we advance a third perspective which is that successful implementation leads to desire... impact from whatever program is being 
analyzed." So, there are three perspectives used to measure the success of implementation of policy.

Based on the problem and theoretical approaches described, the writer conduct a research entitles Implementation of District's Integrated Administration Service (PATEN) in Gunung Putri District of Bogor Regency.

\section{Research Methods}

The research is conducted using qualitative approach. In this case the research is not aimed to measure the strength and the relationship among the variables but more intended to describe the situation, phenomenon (phenomenology), situation, and process. The approach in qualitative research is also called as investigation approach because the researcher collects the data by directly meet the people in research location (McMillan \& Schumacher, 2003). Qualitative research also means as the research type where the findings not obtain through the statistical procedures or other calculation forms (Strauss \& Corbin, 2003). The analysis is qualitative which emphasizing the meaning than generalization against the object observed.

The type of data used in this research consists of primary and secondary data. Secondary data is the types of permit which under the authority of PATEN in the level of Gunung Putri District, Bogor Regency. Beside the secondary data, this research specially uses the primary data for analysis of study. Primary data includes various informations about the policy of PATEN in Administration Department of Government of Bogor Regency, Gunung Putri District, and PATEN in Gunung Putri District obtained from the interview result with various interviewees (in-depth interview) or Focused Group Discussion (FGD).

The secondary data are documents, statistical data, and many others compiled from various authorized agencies. Using qualitative approach then the instrument is someone or the researcher himself (human instrument). To be the instrument then researcher should have large theoretical and knowledge, thus able to ask, analyze, and construct the observed social situation become clearer and more meaningful. Therefore, the primary data is obtained through two ways namely (1) in-depth interview and (2) focused-group discussion (FGD) and expert meeting.

In-depth interview is intensively conducted to investigate the interviewee's perspective about PATEN in the level of Regency, District. This method is chosen because more suitable to investigate the information from every interviewees in more depth as well as flexible in carrying it. Although in-depth interview is focused to investigate about the licensing service implementation in Bogor Regency, but in its implementation it still provides discretion and space for the researcher and interviewees to explore the issue in the framework of interview guideline. The interview is conducted to the interviewees of Regional Government and the people, the service user; a). Regency Government of Bogor, they are the Head of Government Administration Division: Ujang Supendi, SH, MH., b). Capital Investment Department and One-Stop Integrated Service, that is Head of Data Processing: Judi Rachmat Sulaeli, S.Hut, MM., c). Gunung Putri District, that is Head of Gunung Putri District of Juanda Dimansyah, SE, MM and the Head of Service Division/PATEN :Drs. Ade Kosnia., d). the users of PATEN, they are Akbar Mahu, Santi Oktavia, Edih Pandih, Lindawati, Encim and Ujang Darkim

The data collection is also conducted through the method of focused-group discussion (FGD). The interaction among the participants and their activeness in delivering opinion are 
important in order to obtain valid result. It is important in order to collect the information comprehensively from various points of view of stakeholders. FGD is focused for the topic of improvement of licensing service implementation through the reformation of PATEN organization.

Analysis technique used is descriptive analysis. It is used to explain or describe the data of observation result and interview with the interviewees. This analysis is aimed to collect the overview of District's Integrated Administration service (PATEN) at present and in the future through various data and information from the main interviewees. The analysis result provides information as the basic of decision making related to the strategy of implementation and the improvement efforts of licensing service in Gunung Putri District of Bogor Regency.

\section{Finding And Discussion}

\section{The Compliance toward the Regulation of Laws}

\section{Public Service Organization}

The policy of Public Service in District level was based on the Regulation of Minister of Home Affairs Number 4 of 2010 concerning the Guideline of District's Integrated Administration Service (PATEN) and the Decision of Minister of Home Affairs Number 138270 of 2010 concerning the Technical Guideline of Integrated Administration Service (PATEN), thus the Head of District became the administrator in public service in his area whereas PATEN was the transformation of service division has existed during this time. Then, in its implementation, PATEN only provided service in civil affairs such as Identity Card, Family Card, birth and dead certificate and other things related to the civil affairs as well as the public service of licensing settled by the Government Division in District Office.

Meanwhile, the public service policy in District level had applied the policy of Laws Number 23 of 2014 concerning Regional Government that is Article 350 "Regional leader must establish One-Stop Integrated Service unit and in accordance with article 39 of Government Regulation Number 18 of 2016 about the function of One-Stop Integrated Service combined with the function of Capital Investment accommodated in Capital Investment and One-Stop Integrated Service Department which receive authority on licensing service determined by the Regional Government of Bogor Regency Number 12 of 2016 concerning the Capital Investment and One-stop Integrated Service.

Therefore in Bogor Regency, the implementation of Laws No. 23 of 2014, in the case of public service had not implemented in integrated and holistic. PATEN in District not has hierarchy relationship with the Department of Capital Investment - One-stop Integrated Service because it was under the coordination of Government Administration Division of Regional Secretary of Bogor Regency.

The implication of dualism of those policies, PATEN in district level completely followed the policy formulated by Government Administration Division including the determination of service standard, while the policies in the Department of Capital Investment - One-stop Integrated Service including the determination of service standard was only applied internally in that department and not applied in the District as stated by the Head of Government Administration Division (Ujang Supendi, SH, MH) below: 
The service policy in District level organized by PATEN, until now the service standard is followed the standard formulated by the Government Administration Division of Bogor Regency, whereas the service standard of the Department of Capital Investment - One-Stop Integrated Service is only applied internally in the department/regency level.

\section{PATEN in Gunung Putri District}

The delegation transfer of authority of some government affairs to the Head of District based on the Regent Regulation of Bogor No. 66 of 2010 dated 22 November 2010 and the Regent Regulation of Bogor No. 51 of 2013. In addition was the Regent Regulation of Bogor No. 25 of 2014 dated 15 September 2014 determined the description of duties of PATEN personnel in Bogor Regency.

On those regulations the service standard non-licensing has been determined, that was the document which stated the legality given by regional government toward individual or legal entity based on the regulations of laws (letter of notification, recommendation, etc.). In the article 34 of Regent Regulation of Bogor No. 13 of 2014 concerning the Procedures Operational Standard of Licensing and Non Licensing in District determine the period of non licensing service not longer than 3 days since the document was confirmed as complete. According to the result of interview with the informant stated that all non licensing service has appropriated with the Procedure Operational Standard but the Electronic Identity Card service which the finishing time was unsure.

According to the Regulation of Minister of Home Affairs No. 19 of 2018 concerning the improvement of civil administration service quality, the process of issuing the civil document should be done in the period of 1-24 hours including the settlement of electronic Identity Card. However, in fact Electronic Identity Card needed much time even until 2 years. It was because the external problems including the procurement of form of Electronic Identity Card and the process of unity checking of data in the system of data center of Home Affairs Ministry.

The unimplemented standard operational procedures were including the monthly report regulated in article 80 of Regent Regulation of Bogor No.13 of 2014 and article 13 of Regent Regulation of Bogor No.51 of 2013, because the document were not found when the research was conducted.

According to Edward III (in Agustino 2008 : 153-158) that may improve the performance of implementation is Standard Operating Procedures (SOPs) which become the reference for the workers in conducting the daily activities. In the other hand, Ripley \& Franklin, 1986:11 said that there were two perspective of compliance namely (1) many non bureaucratic factors affected but in fact were less considered, and (2) the program that improperly designed thus affected the implementation process.

Based on the research result, we known that SOP in the service not obeyed yet and may affect the performance of implementation. Moreover, the existence of non bureaucratic factors and improperly designed program will affect the implementation process.

\section{The Problems Found}

According to the interview result with Head of PATEN Service Division, Drs. Ade Kosnia said that various problems in implementation of PATEN in Gunung Putri District were; a). In the aspect of Human Resource/ Personnel, were only two workers with Civil Servant while the rest were job exempts without training initially, b). The budget was less even there was no budget for operational cost, c). The aspect of work facilities, there was no 
lactation room and play ground for children while the parents waiting for the service, d). The computer and printer was less, thus it holds up the smoothness of duties, and e). For the officers, they considered that the regulation of PATEN was frequently change and the status of PATEN that dependent (not depend on the Head of District/ District) cause the principle of fast service may be obstructed, because most of the licensing service should be through and signed by the Head of District.

From the description stated by Head of Service Division of PATEN, it showed that Regional Government of Bogor Regency in realizing the vision of PATEN was: realizing the people satisfaction through the integrated service still need more support.

\section{The Service Performance and the Impact Expected}

The Performance Accountability System of Government Organization is the accountability practice in Indonesia that has been started since 1999. Through the Regulation of Ministry of Administrative and Bureaucratic Reform No. 29 of 2010 concerning the guidelines of preparation of performance determination and performance accountability report of Government Organization, is the obligation for every Work Unit of Regional Government and independent work unit. The policy is started by the arrangement of RPJMD that based on the article 64 of Regulation of Ministry of Home Affairs No.54 of 2010 and its operational of strategic plan of Work Unit of Regional Government and independent work unit, in this case is Gunung Putri District of Bogor Regency.

In this research the work unit plan of District of 2014-2019 could not be found and showed but referred to the report uploaded on 31 March 2018 the Performance Accountability Report of Government Organization of Gunung Putri District, Regency Government of Bogor 2017.

The Performance Accountability Report of Government Organization provided information below: a). the content was not in accordance with the Regulation of Ministry of Administration and Bureaucratic Reform No. 29 of 2010 concerning the Guideline of Preparation of Performance Determination and Performance Accountability Report of Government Organization, because not contained information expected in the guidelines for instance the comparison of achievement of performance indicator until the year run with 5 yearly performance target designed, b). PATEN activities during 5 years were not reported thus the Service Performance and the impact expected was unknown.

The implementation of service policy of PATEN in Gunung Putri District according to the theory proposed by Ripley \& Franklin, 1986:11 the success of policy/program was reviewed based on the implementation process and result perspective. In the process perspective, government's program in this case the public service is success if the implementation in accordance with the guidelines and the provisions designed by the program creator that include the implementation ways, agent, target group, and program benefits, while in the result perspective, the program is success if it gives the impact as expected.

According to the description given, if related to the theory proposed by Ripley \& Franklin, it can be concluded that the success of PATEN program in Gunung Putri based on the implementation process and result perspective, the performance could not be measured thus the output, outcome, benefit and the impact could not be analyzed. 


\section{Conclusion And Suggestion}

\section{Conclusion}

The compliance on the Regulation of Laws in the implementation of PATEN, can be confirmed that the compliance degree is low because various Regent Regulations about implementation and determination of standard operational procedures not completely implemented, b). found various problems for instance in the aspect of Human Resources/ Personnel, Budgeting, work facilities, computer and printer, regulation that frequently change, and dependent organization of PATEN affect the principle of public service as regulated in the Laws No. 25 of 2009 not fully implemented, c). the service performance and impact expected, cannot be measured because there is no complete document of work unit plan design and Performance Accountability Report of Government Organization that in line with the guideline of report preparation. Those three perspective did not run smoothly and it means that the implementation of PATEN policy in Gunung Putri District of Bogor Regency not work properly.

\section{Suggestion}

The suggestion for the Regent of Bogor Regency are: a). according to the regulation of Laws No. 23 of 2014 concerning regional Government, to realize the establishment of OneStop Integrated Service that has functional and operational relationship with the Department of Capital Investment and One-Stop Integrated Service of Bogor Regency, b). the duties and function of Head of District should refers to the PP No. 19 of 2008 article 15 concerning District and PP No. 41 of 2007, particularly support the people participation in development, community empowerment, and fostering the implementation of village governance, c). conducting technical training for all staff of One-Stop Integrated Service, in order they have same competency standard in every implementation unit, and d). to the implementation unit of PATEN that will transform into One-Stop Integrated Service, should do their duties based on the work plan/performance target, completing the service facilities based on the standard and providing the service based on the principles of service determined.

\section{Acknowledgement}

By saying Alhmadulillah, the writer has finished the research report entitles: Implementation of District's Integrated Administration Service Policy in Gunung Putri District of Bogor Regency.

Finishing the present research cannot be separated from the support of some parties, namely:

1. Mr. Dr. Ir. Panji Hendrarso, MM, the Rector of Social Science and Management Institute of STIAMI who provided the fund facility that enables this research can be finished.

2. Mr. Dr. Yulianto, SE, MM, the deputy rector I of Academic Division, who gave the technical guidance start from the proposal arrangement until the report and reviewed the current research.

3. Regency Government of Bogor, particularly the Head of Kesbangpol, Head of Capital Investment and One-Stop Integrated Service Department and the head of Government Administration Division who provided the data and information required for this research. 
4. The Head of District and Head of PATEN service division of Gunung Putri District who facilitated the research location and support the providing data and information required.

5. People of Gunung Putri District who contributed as the informant.

Therefore, we say thank you very much to them and highly respect to all their support and attention for the success of the current research. Hope Allah SWT always blesses us.

\section{References}

[1]. A, Strauss dan Corbin J., 2003, Dasar-Dasar Penelitian Kualitatif : Tatalangkah dan Tekni-teknik Teorisasi Data, Pustaka Pelajar, Yogyakarta.

[2]. Agustino, Leo. 2008. Dasar- dasar Kebijakan Publik. Alfabeta: Bandung.

[3]. Akib,Haedar.2010. Implementasi Kebijakan : Apa, Mengapa dan Bagaimana. Jurnal Administrasi Publik Vol. 1 Nomor 1 Tahun 2010

[4]. Al Fatih, Andy. 2010. Implementasi Kebijakan dan Pemberdayaan Masyarakat. Bandung: UNPAD Press.

[5]. McMillan, James H, \& Sally Schumacher. 2003. Research in Education. New Jersey: Pearson

[6]. Pitono, Andi, 2011, Implementasi Kebijakan Pendelegasian Wewenang Dari Bupati Kepada Camat Bidang Pengembangan Otonomi Daerah dan Kependudukan, dalam Jurnal Pamong Praja - Memikirkan dan Mencerahkan Pemerintahan, Jakarta : DPN- IKAPTK, volume I, Nomor 2, Tahun 2011.

[7]. Porwanto dan Dyah Ratih Sulistiatuty. 2012. Implementasi Kebijakan Publik: Konsep dan Aplikasinya di Indonesia. Yogyakarta. Gava Media.

[8]. Ripley, Ronald B and Grace Franklin. 1986. Policy Implementation Bereaucracy. Chicago : Dorsey Press.

[9]. Rondinelli, Nellis, and Cheema G Shabir, 1984. Decentralisation in Developing Countries. World Bank.

[10]. Smith.B.C (1985) Decentralization:The Territorial Dimension of The State.London: George Allen \& Unwin.

[11]. Wasistiono, Sadu, Ismail Nurdin \& M. Fahrurozi. 2009. Perkembangan Organisasi Kecamatan Dari Masa Ke Masa. Bandung: Fokusmedia.

[12]. Kosasih, 2014. Analisis Kualitas Implementasi Pelayanan Administrasi Terpadu Kecamatan (PATEN) Di Kantor Kecamatan Gunungputri Kabupaten Bogor, Jurnal Reformasi Administrasi Vol. 1 Nomor 2. September 2014

[13]. Yuli Tirtariandi El Anshori, Enceng dan Anto Hidayat, 2014 Jurnal Ilmu Administrasi Negara, Volume 12, Nomor 4, Januari 2014: 229-240

[14]. Undang-Undang No. 25 Tahun 2009 Tentang Pelayanan Publik Undang-Undang No. 23 Tahun 2014 Tentang Pemerintahan Daerah

[15]. Peraturan Menteri PAN-RB No. 29 Tahun 2010 tentang Pedoman Penyusunan Penetapan Kinerja dan Pelaporan Akuntabilitas Kinerja Instansi Pemerintah

[16]. Peraturan Menteri Dalam Negeri No. 4 Tahun 2010 Tentang Pedoman Pelayanan Administrasi Terpadu Kecamatan

[17]. Peraturan Bupati Bogor No. 66 Tahun 2010 Tentang Pelimpahan Kewenangan Penyelenggaraan Sebagian Pemerintahan Kepada Camat

[18]. Peraturan Bupati Bogor No. 51 Tahun 2013 Tentang Pendelegasian Kewenangan Penandatanganan Dokumen Administrasi Pelayanan Perizinan Dan Non Perizinan Kepada Camat

[19]. Peraturan Bupati Bogor No.13 Tahun 2014 Tentang Standar Operasional Prosedur Pelayanan Perizinan Dan Non Perizinan Pada Kecamatan

[20]. Keputusan Bupati Bogor No. 137/779/Kpts/Per-UU/2013 Tentang Pembentukan Tim Teknis Pelayanan Administrasi Terpadu Kecamatan Di Kabupaten Bogor

[21]. Keputusan Bupati Bogor No. 138/780/Kpts/Per-UU/2013 Tentang Penetapan Kecamatan Sebagai Penyelenggara Pelayanan Administrasi Terpadu Kecamatan Di Kabupaten Bogor 